\title{
Application of Color and Graph in Packaging Design for Children's Products
}

\author{
Bianling Zhang \\ Huanghe Science and Technology College \\ Zhengzhou, China
}

\begin{abstract}
Purpose Analyze the effects of color and graphic design on children's consumption behavior. Method Divide the children's growing development into 3 periods - infancy, preschool period, children's period, summarize the perceived responses to the color and graphics of commodity packaging at all ages and compares the package for children's products in markets through the analysis of the physiological, psychological and cognitive characteristics of children in these three stages. Conclusion To sum up the lessons learned, promote the ideas and methods to children's product children's packaging in color design and graphic design, promote the foresight and guidance to the packing design for children's products, advocate national original design elements, promote children's national awareness and national identity, improve children's products packaging the level of business and achieve a win-win situation for consumers and children.
\end{abstract}

Keywords — children; color; graphic; commodity; packing

\section{INTRODUCTION}

Before the age of 12, the growth and development of children can be divided into three stages, namely the pre-3year-old, 3-6 years of age and 6-12 years of age. Children of different periods have the different characteristics to the perception and needs of things, if the production and packaging of children's products can be designed and made according to the characteristics of physical and mental development of children with different ages, it will be a winwin situation for businesses and consumer.

In order to get consumer recognition the good products also should have a good packaging. Well-known US packaging design company Primo has a motto: children are generally consumers, regardless of product and packaging. For most products, the product is packing, the packing is product. [1]Good merchandise refers to not high-end or luxury products but suitable ones, the excellent packing for children's products not only can expand the children's consumer market, but also meet the needs of children in all aspects, promote children's physical and mental health. Discuss the color and graphic used in the packing for children's products combined with some packaging of children's products in the market. Explore the role of the color and shape in the packaging of children's products, and put forward constructive suggestions and suggestions to promote the prosperity of children's products market so that children can grow up healthily and happily.

\section{PACKING DESIGN OF CHILDREN'S PRODUCTS FOR INFANCY}

Before 3 years old, the children's scope of activities is not large, more depend on adult protection and guidance in this period, the most important thing is toys and food appliances, the choice of food appliances is mainly judged by the eyes of parents because of weak autonomy during this period. The ancient Greek philosopher Jonathan once said: "Color is the material form of the initial phenomenon."[2] In the eyes of parents, children in this period like a drop of morning dew, bright, delicate, color choices in daily necessities are the mainly focus on lightness, low purity of color- bright \&soft-no strong contrast and sharp image, everything is soft as the premise.

A few months old baby will be able to respond to the color, Steeble has done such an experiment, presents two discs of equal brightness to the baby and measure the gazing time, 3 months of infant vision remain in the color circle about 2 times than the gray disc, indicating that infants and young children are more interested in the color saturation. Early childhood children do not have much autonomy, but can show obvious likes and dislikes; at this time, the children are not very concerned about the content of the toy, but choose the toys the color and graphics, the packaging image is simple, high color saturation toys will be more popular in this age children, infancy children's perception of color is mainly red, yellow, blue and other solid colors. Their vision is narrow, the familiar graphics are mainly square, round and other simple basic shape, the pattern on the supplies are mostly simple animal or plant or character image. Children, from the psychological point of view, choose their own "control" toys, and form the dependence on the toy partner in a sense of security as the premise. Therefore, early childhood children are more willing to choose their familiar toys.

It is one of the important issues on color design that adjust the relationship among the color brightness, hue and purity to meet the physical and psychological needs of children.[3]The packing color of infant's products in most of the market is pure, the graphic is simple and lovely, but there are some of them adopt the strong color and too complex design. Such as some puzzle toys, in addition to square, round and other basic shape, there are a large number of complex animal-shaped, and even irregular shape, make-up color variety, these products seem very attractive, in fact, not suitable for infant. 


\section{PACKING DESIGN OF CHILDREN'S PRODUCTS FOR PRE- SCHOOL PERIOD}

Compared with early childhood, the activities scope of the pre-school children is expanded, the understanding to things are further enriched, the autonomy of the choice of items is further strengthened, and the using types of goods are also more abundant. The children's consumer psychology in this period can be summed up as the following characteristics: (1) have a strong herd mentality, the expansion of the scope activities provide the chance for them to access to more people and things, especially among children, others' things must be good, he must have the things that some children have. They want to be consistent with others to prove that he is a member of the group; this is a social manifestation of children at this stage. (2) Curiosity, different form the infancy, the courage of the preschool children is also growing with age, they have a strong desire to explore the objective things, like know the root of one problem, willing to accept new things, and very interest in the things which they do not see and play. (3) Many interest points, and the interests are transferred very fast, because the child's physiological and psychological state is not yet mature, their buying behavior is mainly affected by emotional motives, showing impulsivity, irrational and unstable, their needs to goods are often improvisation, no plans, they want to have it when they see, and sometimes even they are interested in it when they buy, but will put it onside after backing home. [4].

In many packaging factors, the color is the first factor in the packaging of children's goods; the designer makes the confusing effect with color and color affinity and contrast. The irrational characteristics of children's consumption determine their choice of goods only depend on their likes and dislikes, the packaging of other factors for this period of children is useless. They do not care about the material, texture, quality and other factors; therefore, packaging color at this time is an important factor affecting children's consumer psychology.

People transfer the image and color via vision, in the visual transformation process, the color is better than the image. According to the characteristics of pre-school children, the color of goods packaging should be more intense contrast, which is easy to be found by children in many commodities, according to preconceived behavior, the first to find is the best, children will have a strong sense of ownership, and then induce purchasing behavior. Children in this period like novelty and distinctive goods, in the use of color, in addition to strong contrast, you can break the taboo of the usage of some traditional color, and bravely adopt the new color relations to create a NON BUT ME emotional atmosphere to guide their consumption. Such as the Trunki children's luggage trolley box of United Kingdom won a number of international design awards, set the functionality and practicality in one case with a large area of solid color, matched with the bold contrasting color, which can instantly attract children's eyes, the handles of the case are similar to the antennae of animals which can be used as handrails for children when riding, this case are perfect in shape, color, function. In the choice of graphic patterns, preschool children can accept some complex image, but they are more willing to accept their familiar image, the modern children are influenced a lot by television, animation, the cartoon image on television are liked very much by them, such as Disney cartoon image, Duola A dream, Happy sheep and Gray Wolf etc.

\section{PACKING DESIGN OF CHILDREN'S PRODUCTS FOR CHILDREN'S PERIOD}

The children's period is very long, including the whole process from primary school to middle school. During the children's period, the link between the children and the outside world is increased, the used goods is more rich with more autonomy, in addition to food, toys, the consumption to clothing \& stationery consumption are added. Compared with food and toys, the consumption to clothing and stationary is increased with the increasing age and the portion of them is become heavier, during this period, the independence ideas of them are more obvious, they are more rebellious, and willing to show their difference in all aspects, thus, they tend to choose the novel and different goods. In this context, packaging has become as the most important factor in commodities for the school age children. On the dazzling shelves in supermarkets and warehouse-style shopping malls, a variety goods contest with each other, a survey shows that children observe each commodity within $0.25 \mathrm{~s}$ or so, this glance decides whether the goods can attract the attention of children's consumers. The color is used on packaging to attract the attention of customers, but it will not be successful that blindly enhance the color contrast; the designer must use the color according to the use and characteristics of products.

In the use of packaging graphics, Mickey Mouse, Donald Duck, Pleasant Goat, Wolf and other images can not meet their needs, they need more "cool" more "shine" design to highlight personal style. Boys prefer to the images like fight King, Naruto, Dreaming westward journey etc, girls like the Sailor Moon Warrior, Balala little fairy magic. The children's athletic cartoon broadcasted on TV is more closer with their game world; the manufacturers spend huge sums to build animation, the real purpose is to promote the animated cartoon derivatives - animated toy products, according to the children characteristics, the manufacturers design the image and plot in the cartoon, and make the appropriate product to attract children's attention and love to achieve the sales purposes.

\section{The CurRent Problems And SOlving Methods}

Children of different ages have different preferences and characteristics in the selection of goods. As a child packaging designer, the first thing to do is to adapt and meet the needs of children. The current children's products market is a wide range, and the packaging design has also been improved, but the there are still some problems on packaging color and graphics design.

In the packaging color, the first is to pay attention to the changes in color sense for packaging design, it is not right that the children like bright colors and colors with strong contrast, and take the bright color as the standard for packing color. Some manufactures do not consider the color relationship itself, subjectively make the fancy, dazzling packing for goods, and think that the children's attention will be attracted by using many kinds of colors, which is totally wrong. Aesthetic and 
habit needs of children played a very important role in the choice of color.

From the market level, the manufacturer should have a sense of crisis, children's products market, regardless of the broad prospects, just from the enterprise development and brand development, the children's products manufacturers should make goods with good quality, meanwhile, they should put the packing color and image design to a strategic height, identify the product positioning, carefully study the psychological and behavioral habits of children of all ages, design the packing of products from the overall development of enterprises and corporate culture to avoid short-sighted behavior.

Our country can provide some assist to the enterprises from the policy and guidance, it is possible to set up the competition for special packaging and image design for children's products, or clarify and evaluate the packing and image design of the children's products, give award to the original, environmental, active and healthy product image and packaging and public them through the media to form the atmosphere and public direction and then form the long-term mechanism to force the enterprises to pay attention to product packaging design, seriously research the packaging design, so that integrate the product quality and packaging as an organic whole, and develop together.

\section{CONCLUSION}

Children's product packaging design should also be forward-looking and guidance. Children are the future of the country; all aspects referred to their growth should be paid enough attention, on basis of meeting the needs of the children, the packaging should not blindly cater, but moderately guide. If the packaging image is only a simple imitation and use the foreign cartoon image, it will make the children form an impression that the foreign products are better than the domestic ones. Energetically develop the national enterprises in the development of children's products, promote the original image of our own in large-scale scope, and train the children's national consciousness and identity in their life and learning aspects, which will benefit both the children and enterprises. Hope that designers and manufacturers to establish a national consciousness and brand concept to integrate the design of goods, production, packaging organically together, according to the characteristics of children's packaging products to create more products which are favorite and suitable for the Chinese.

\section{REFERENCES}

[1] Xiangyang Wang, Haiming Du, Wanchun Huang, The relationship between the Children's consumption psychology and packing color of the children's food, Packing engineer, 2008.08, 29(8), page 111-112

[2] Lin Wang, The brightness of the packing color and its function in the sales of commodity, Packing engineer, 2012.07, 33(14), page 123-126

[3] Lei Ying, Yi Sun, Discuss the color application in the packing for children's products from the color emotional skills of the children, Packing engineering, 2007.10,28(10), page 171-173

[4] Jianing Zhang, Yi Tan, Research and discussion on the additional function of the packing design of children's product, Packing engineering, 2012.07, 33(14), page 80-83 